\title{
Lumen
}

Selected Proceedings from the Canadian Society for Eighteenth-Century Studies

\section{Does a Dutiful Wife Write; or, Should Suzanne get Divorced? Reflections on Suzanne Curchod Necker, Divorce, and the Construction of the Biographical Subject}

\section{Sonja Boon}

Volume 27, 2008

North America at the Crossroads of European Cultures in the Eighteenth Century

L’Amérique du Nord au Carrefour des cultures au XVIII ${ }^{\mathrm{e}}$ siècle

URI : https://id.erudit.org/iderudit/1012050ar

DOI : https://doi.org/10.7202/1012050ar

Aller au sommaire du numéro

Éditeur(s)

Canadian Society for Eighteenth-Century Studies / Société canadienne d'étude du dix-huitième siècle

ISSN

1209-3696 (imprimé)

1927-8284 (numérique)

Découvrir la revue

Citer cet article

Boon, S. (2008). Does a Dutiful Wife Write; or, Should Suzanne get Divorced? Reflections on Suzanne Curchod Necker, Divorce, and the Construction of the Biographical Subject. Lumen, 27, 59-73. https://doi.org/10.7202/1012050ar

Copyright (c) Canadian Society for Eighteenth-Century Studies / Sociéte canadienne d'étude du dix-huitième siècle, 2009
Ce document est protégé par la loi sur le droit d'auteur. L'utilisation des services d'Érudit (y compris la reproduction) est assujettie à sa politique d'utilisation que vous pouvez consulter en ligne.

https://apropos.erudit.org/fr/usagers/politique-dutilisation/ 


\section{Does a Dutiful Wife Write; or, Should Suzanne get Divorced? Reflections on Suzanne Curchod Necker, Divorce, and the Construction of the Biographical Subject}

The life of Suzanne Curchod Necker is the stuff of which fairytales are made: young, beautiful, tragic and impoverished heroine meets successful, hardworking and wealthy life companion before settling into a comfortably affluent life of virtuous domestic bliss. ${ }^{1}$ In reality, however, Suzanne Curchod Necker was much more than a fairytale heroine. She was born Suzanne Curchod on the second of June 1737 in the small Swiss town of Crassier, near the French border. From her father, a Calvinist minister, she received a comprehensive education which far surpassed that of most young women of her class. ${ }^{2}$ From her mother, she received her beauty and her vague claims to a noble French background. ${ }^{3}$ By her teenage years, she was a social success: "la belle Curchod," as she was now known enjoyed the attentions of numerous admirers and reigned over her own salon, the Académie des Eaux. ${ }^{4}$

Her largely happy youth ended, however, with the deaths of her parents in 1761 and 1763. Less than a year later, she left her native Switzerland for good, and travelling as the companion of a family friend,

1 I refer throughout to the two Necker family members as Suzanne Curchod Necker (her full married name) and Jacques Necker.

2 Paul-Gabriel d'Haussonville, Le salon de Madame Necker (Paris: Calmann Lévy, 1882), 2:13.

3 Ibid. 1:15; 1:11.

4 Ibid. 2:27-28. 
settled in Paris in 1764. There, in the glittering splendour of Europe's most famous city, Suzanne Curchod captured the eye and heart of the hard-working and successful Swiss banker, Jacques Necker. They were married within the year and just one year later, Suzanne gave birth to her only child, a daughter. One year after that, Suzanne Necker established a salon, which, unsurprisingly, was a great success. And then, as they say, she lived happily ever after: not only did she lead a successful salon, but she also maintained an active correspondence with many of the luminaries of the French Enlightenment, and put her moral and philosophical ideals into practice through a strong commitment to matters of social justice.

Her biographical legacy, however, is not nearly so dynamic as her life appears to have been. Instead, biographers have focussed almost exclusively on Suzanne Curchod Necker's status as a model wife: a patient, dutiful, and loving woman who would do anything for her husband, including sacrificing her personal ambitions. Indeed, biographers have been struck by the singular relationship between Suzanne and Jacques Necker. Ste. Beuve, for example, notes Suzanne's "culte de son époux." ${ }^{15}$ The impressions of E. Lairtullier are even more emphatic. In a publication entitled Les femmes célèbres de 1789-1795, et leur influence dans la révolution, a work which includes biographical sketches of, among others, Charlotte Corday and Marie-Jeanne Roland, Lairtullier notes of Madame Necker that: "Jamais union ne fut plus sympathique de coeur et de pensée" and later, "En un mot, ces deux existences se fondirent tellement en une seule, que tracer le tableau de l'une c'est faire connaître celui de l'autre" ${ }^{\prime \prime}$

However, the most enduring aspect of this biographical legacy is the construction of Suzanne Curchod Necker as a woman who did not write. The Marquis de Lally-Tollendal, for example, asserts that she gave up her literary ambitions in order to appease her husband. ${ }^{7}$ An assertion given further credence by the 1882 biographical work of Su-

5 Charles-Augustin Sainte-Beuve, Causeries du lundi (Paris: Garnier Frères, 1853), 4:195.

6 E. Lairtullier, Les femmes célèbres de 1789 à 1795, et leur influence dans la révolution (Paris: Chez France, 1840), 1:107; 1:114.

7 "Madame Necker, à peine mariée avait désiré de se placer honorablement parmi les écrivains; mais son mari lui exprima une fois d'une manière délicate, qu'il se croirait moins nécessaire à une femme dont l'amour-propre serait excité par ses succès littéraires: c'en fut assez pour qu'elle renonçat aux travaux qu'elle avait commencé. Elle se contenta de la conversation et de la correspondance pour manifester ses idées" (Trophime Gérard, Marquis de Lally-Tollendal, “Necker, Suzanne 
zanne Necker's great-great-grandson, Paul-Gabriel d'Haussonville. ${ }^{8}$ The staying power of this image has been immense. Numerous biographical studies of the early twentieth century have perpetrated the myth ${ }^{9}$ including the comparatively recent work of Dena Goodman. ${ }^{10}$

To be fair, these scholars could draw on the words of both Suzanne Curchod Necker and her daughter Germaine de Staël to support their cases. In an unpublished letter to a close friend, Suzanne Necker suggests that she gave up her love of letters for the sake of her domestic obligations as a wife, a statement with which her daughter concurs. ${ }^{11}$ However, the letter in question dates from 1779, well before the appearance of Suzanne Necker's first published work. Her daughter's comments appear in her Journal de jeunesse, a diary written prior to her marriage in 1786. Neither statement, therefore, would support the wholesale construction of Suzanne Curchod Necker as a woman who did not write.

But while the biographical and auto/biographical records have constructed the model of a good wife who acquiesced to her husband's demands, the bibliographic record provides another perspective. From this perspective, it is evident Suzanne Necker did not stop writing when she married, as biographers have argued, but wrote and published throughout her life. These later writings include ten years of annual re-

Curchod de Nasse," Biographie Universelle. Nouvelle édition [Paris: Madame C. Desplaces, s.d.], 31:274-5.)

8 Haussonville, Salon, 1:9-11.

9 See, for example Mark Gambier-Parry, Madame Necker, Her Family and her Friends, With some Account of her Husband's Three Administrations (London and Edinburgh: William Blackwood, 1913); André Corbaz, Madame Necker, Humble Vaudoise et Grande Dame (Lausanne: Payot, 1945); Pierre Kohler, Madame de Staël et la Suisse (Lausanne: Payot, 1916); and the biographical sketch included in Evelyn Beatrice Hall, The Women of the Salons and Other French Portraits (London: Longmans, Green, 1901).

10 Dena Goodman, "Filial Rebellion in the Salon: Madame Geoffrin and her Daughter." French Historical Studies. 16, vol.1 (1989): 28-47.

11 Suzanne Curchod Necker writes: "les occupations dont je suis accablées et le peu de moyen que j'ai pour y suffire vous montreroient aisement que tous les états ont leurs fatigues et leur fatigues et leur contrariétés; j'ai été obligée de sacrifier entierement a ma position le gout que javois pour les lettres" in "Lettre à Mme de Branles, 15 avril 1779." In Fonds Clavel, IS1915 xxx/h/1. Bibliothèque cantonale et universitaire de Lausanne (original spelling maintained). Germaine Necker concurs, writing that: "Maman avoit fort le gout de composer; elle le lui [Jacques Necker] a sacrifié," in Béatrice d'Andlau, La jeunesse de Madame de Stä̈l (de 1766 à 1786) (Paris and Geneva: Librairie Droz, 1970), p. 110. 
ports for the Hospice de charité, an experimental charity hospital established by Suzanne Necker in 1778, a treatise against premature burial, five volumes of posthumously published personal writings and, finally, the Réflexions sur le divorce, an impassioned defence of marriage written during the final years of her life and published posthumously within a few months of her death. ${ }^{12}$

In this paper, I want to explore the discrepancy between biographical construction and autobiographical performance through an examination of the fluid nature of auto/biographical presentation. In particular, I look at what I perceive as the political motivations behind the crafting of Suzanne Necker as a biographical subject and contrast this with an alternative reading of Suzanne Necker as an autobiographical performer. I want to argue that the biographical construction of Suzanne Necker is directly implicated in the politics of divorce in France, from the original 1792 revolutionary law authorizing divorce, through the turbulent nineteenth century. A century which saw divorce challenged, revoked, and ultimately reinstated. I also want to suggest that the construction of Suzanne Necker is intimately tied to the social understandings of women which propelled the politics of the various divorce laws.

I will begin by situating the biographical record within the context of a century of French divorce legislation, examining closely the ways in which Suzanne Necker was positioned as the 'poster woman' for the case against the legalization of divorce. I will explore the implications of such a reading before moving on to a discussion of Suzanne Necker's life through her public works and her correspondence as well as through the eyes of her contemporaries. Finally, I will explore ways in which it might be possible for Suzanne Necker to divorce herself from her biographical constructions and examine the possibilities for a new biographical writing. In other words, should Suzanne get divorced, and what might happen if she does?

Marriage was desacralized in France and declared a civil contract in the constitution of 3 September 1791. One year later, in September 1792, the Assemblee Nationale instituted true divorce laws. Divorces could be granted on three grounds: matrimonial fault (which did not

12 Suzanne Curchod Necker, Réflexions sur le divorce (Lausanne: Durant \& Ravanel, 1794); Suzanne Curchod Necker, Des Inhumations Précipitées (Paris: Imprimerie Royale, 1790); [Suzanne Curchod Necker], Hospice de charité (Paris: Imprimerie royale 1781); [Suzanne Curchod Necker], Hospice de charité: institutions, règles, et usages de cette Maison (Paris: Imprimerie royale, 1780); Suzanne Curchod Necker, Mélanges: Extraits des manuscrits de Madame. Necker. 3 Vols. (Paris: Charles Pougens, 1798); Suzanne Curchod Necker, Nouveaux mélanges. 2 Vols. (Paris: Pougens, 1801). 
include adultery), mutual consent, and incompatibility. ${ }^{13}$ During the twenty-five year period which followed, the divorce law was modified and restricted under the Napoleonic civil code, and finally, under the Bonald law of 1816, suppressed altogether in order to appease the Catholic Church. After this, divorce was not legalized in France until the introduction of the Naquet law in 1884.

From the outset, Suzanne Necker's Réflexions sur le divorce positions itself in direct opposition to the 1792 legislation. In particular, she argues that this "dangerous law" separates spouses, isolates children, works against all natural affections, and has the capacity to wholly undermine "la Patrie." ${ }^{14}$ She insists that the indissolubility of marriage must be upheld in order to ensure the happiness of the spouses, both in youth and old age, the happiness of their children and, finally, the maintenance of social mores and conventions. ${ }^{15}$ Suzanne Necker argues that the legalization of divorce would have particular consequences for women, who are by nature unsuited to the solitary life, "plus particulièrement destinées à n'avoir jamais une existence isolée, mais plutôt à devenir le complément de celle des autres." ${ }^{\prime 16}$

Suzanne Necker's ideal marriage is an affective marriage in which the happiness of the two spouses is of utmost importance: ${ }^{17}$ it is only through the sacrament of marriage that two disparate but equal halves can be united into one whole. ${ }^{18}$ The possibility of divorce, however, renders impossible the realization of the perfect marriage, for, as Suzanne Necker observes:

la loi qui permet le divorce détruira absolument cet effet précieux de l'identité et de l'unité des époux. Quelle femme seroit vaine d'un nom, qui bientôt ne sera plus le sien? Ou d'une gloire, qui peut refléchir sur une autre? Ce sentiment

13 Antony Copley, Sexual Moralities in France, 1780-1980: New ideas on the family, divorce and homosexuality (London,: Routledge, 1989), 21.

14 Curchod Necker, Réflexions, 5.

15 Ibid. 6.

16 Ibid. 27.

17 "Je tâcherai de prouver que le but principal de la Nature, dans l'institution du mariage, [est] le bonheur des deux époux, la reproduction de leur être n'est qu'un but secondaire, que ne doit point influer sur la loi" (Ibid. 13).

18 "Le mariage réunit nos affections éparses; il met deux âmes en communauté de vie, et la différence des sexes et des facultés empêche que ces deux âmes ne soient jamais rivales" (Ibid., 9). 
d'instabilité influe continuellement et imperceptiblement sur nos penchans et sur nos opinions; c'est un grain de sable qui peut empêcher à jamais deux surfaces polies de se toucher dans tous les points. ${ }^{19}$

As an autobiographical gesture, the Réflexions provide a strong foundation for the nineteenth-century biographical constructions of the author which followed. By positioning herself so passionately in favour of the principles of affective marriage, Suzanne Necker reaffirms her commitment to those same principles within the context of her own life. Her position is powerfully confirmed by Jacques Necker's preface, which introduces the work. Jacques Necker, as his wife's first biographer, positions her as a virtuous domestic being eminently worthy of public esteem. ${ }^{20}$ By linking the virtues of the writing to the virtues of the person, he is able to argue that the purity of style mirrors the purity of the thoughts themselves, and, by consequence, the purity of the woman who conceived them. In addition to this, Jacques Necker's authoritative presence in the reflexions serves as a confirmation of the indissolubility of the Necker marriage. This same preface graces the two reprints which appeared in $1802 .^{21}$

The image of Suzanne Necker as a virtuous, loving wife was strategically deployed in the defense of marriage throughout the turbulent period between the initial divorce legislation of 1792 and its ultimate suppression in 1816. Not only were the Réflexions re-issued numerous times, but Jacques Necker also oversaw the publication of his wife's five volumes of personal writings, a carefully-edited and anthologized collection of essays, fragments, maxims and letters designed to further confirm the image of Suzanne Necker as a pious, thoughtful, and committed woman and wife. In the "Observations de l'éditeur" which introduce the volumes, Jacques insists on Suzanne Necker's rightful position within the literary public sphere by emphasizing not only the success which attended the publication of the Réflexions, but also her ability to unite the most disparate ideas while still holding steadfast to

19 Ibid. 18-19.

20 “Je ne sais si jaimais elle l'eût fait paroître, tant elle avoit d'indifférence pour les applaudissemens qu'on décerne aux talents de l'esprit" (Jacques Necker, "Avertissement de M. $\mathrm{N}^{* * *}$," Réflexions sur le divorce [Lausanne: Durant, Ravanel et Comp., 1794], 3.)

21 The work was published in 1794 by Durant, Ravanel et Comp, and then reprinted by two different publishing houses in 1802: Aubin et Desenne in Paris and Lausanne, and Pougens in Paris. 
her Calvinist faith and ideals of moral virtue. ${ }^{22}$ As a result of the work of her husband Suzanne Necker comes across as a virtuous woman endowed with a brilliant mind which she exercises in the moral education of her being. Necker cites in particular the effusive admiration of Antoine-Léonard Thomas, who notes that Suzanne Necker "n'éclaire son esprit que pour rendre son âme meilleure, et chacune de ses idées se transforme en un sentiment moral; elle a suivi cette route toute sa vie, et c'est ainsi qu'elle est parvenue à une pureté et à une élévation de caractère qui a peu d'exemples, et qui est si fort au-dessus du pays et du siècle méprisable où elle vit....son âme est un de ces sanctuaires religieux où l'on ne peut pénétrer sans être ému d'attendrissment et de respect. ${ }^{\prime 23}$ Through these edited extracts and their paratextual presentation Suzanne is thus strategically positioned by both Jacques Necker and Thomas as a counter-Enlightenment voice. She is presented as a generous, virtuous, and moral being who stands in direct contrast to the secular (and even decadent) worldliness that characterized French Enlightenment culture, society, and thought, a lone voice of dedication to traditional values in a century committed to excess of all kinds.

This same image of Suzanne Necker was revived when in the late nineteenth century France was again considering the legalization of divorce. The tenacity and determination of radical deputy Alfred Naquet led to the introduction of divorce bills three times between 1876 and 1881. While all these initiatives failed, the margin was smaller each time. Then in 1881, Adolphe Mathurin de Lescure undertook the republication of Suzanne Necker's Réflexions. Lescure's lengthy opening introductory essay positions Suzanne Necker as a paragon of domestic virtue: Suzanne is an "épouse modèle" and "mère exemplaire."24 Just like Jacques Necker before him, Lescure conflates her life with her work, suggesting that the Réflexions function as a species of lasting autobiographical testament which enables Suzanne's voice to speak, as it were, from the grave. Indeed, Lescure argues that, for Suzanne Necker, the indissolubility of marriage was more permanent than death itself. ${ }^{25}$ Ibid. 1: xviii.

24 Alphonse Mathurin de Lescure, "Étude littéraire et morale sur Madame Necker" Réflexions sur le divorce (Paris: Librairie des bibliophiles, 1881), 1.

25 The full quote reads: "Comme épouse, le chef-d'oeuvre de Mme Necker n'est pas seulement dans l'exemple de sa vie, il est encore dans cet éloquent temoignage qu'elle a voulu donner à la sainteté du mariage, dans ce plaidoyer en faveur de l'indissolubilité du lien conjugal dont l'autorité touchante s'augmente de l'émo- 
It was also at this point, coincidentally, that Suzanne Necker's greatgreat-grandson Paul-Gabriel Haussonville chose to write an extensive biography of his famous ancestor. Le Salon de Madame Necker, a two-volume work still considered definitive, was published in 1882. Haussonville's work builds on the by then well-laid 'good wife' foundation. His Suzanne Necker is intelligent, beautiful, and charming. Her conduct is morally sound and her commitment to Calvinist principles remains steadfast, even within the generally atheistic parameters of the philosophical salon. She is dedicated to her husband and daughter and appears, therefore, to fulfill the tenets of affective marriage as described in the Réflexions.

Haussonville does an exemplary job of reading Suzanne Necker through her husband's career, but he sheds very little light on her own public and political activities. There is, for example, very little discussion of her management and leadership of the Hospice de Charité, an experimental charity hospital founded in 1778 on the dual principles of economics and public hygiene. As one of the two Directors of this project, Suzanne Necker took on a highly visible role as a sort of public relations manager, publishing not only an account of the mission, objectives and goals of the project, but also ten years of accounts which carefully detailed both financial expenditures and medical statistics.

Nor does Haussonville say much about Suzanne Necker's 1790 publication Des inhumations précipitées. ${ }^{26}$ While on the surface merely a treatise on premature burial (of which several were published in the late eighteenth and early nineteenth centuries), it is actually a proposal for a new law designed to guarantee the rights of the physical body during the period between apparent and certified death, complete with all the articles necessary to implement it. Thus, while superficially lightweight, it nevertheless represents a direct intervention into the political sphere.

To a certain extent, this is to be expected. Autobiographical theorist Philippe Lejeune, tracing the history of autobiography as a genre, notes that the proliferation of family autobiographies in the late nineteenth century was directly linked to a desire to maintain the sanctity of the family during a period in which it was perceived that morals were in

tion que provoque son caractère posthume. Il semble ainsi que la voix de Mme Necker sorte de la tombe pour protester que l'amour conjugal, tel qu'elle l'a compris et pratiqué, est plus fort que la mort" (Lescure "Étude" 23).

26 Suzanne Curchod Necker, Des inhumations précipitées (Paris: Imprimerie royale, 1790). 
decline. ${ }^{27}$ Specifically, argues that the practice of autobiography was seen as a "remedy" for social ills; ${ }^{28}$ in other words, the keeping of family records was a way of keeping the family itself from falling apart.

But the scope of the politics of divorce reached further. Historian Teresa McBride asserts that "the political battle over divorce was carried on in the context of a much wider debate about the nature of the French family, the right of the state to intervene in family matters, and in particular, about women's role in the family and in society." ${ }^{\prime 29}$ More specifically, McBride points to social anxiety about emergent women's rights movements and labour unions, as well as to worries about so-called new women, exemplified by the "rising numbers of educated women and by the increase in women teachers and other female government employees. ${ }^{\prime \prime 30}$ What better candidate to refute the claims of new women and to calm the fears of conservatives than Suzanne Necker, the beautiful, intelligent and undeniably conservative wife of the former French finance minister?

Central to Haussonville's conceptualization of his illustrious ancestor is his transcription and analysis of a single letter dating from the early years of Suzanne's marriage. Apparently written during Jacques Necker's tenure as a director of the Compagnie des Indes, this undated letter is filled with passion and sentimentality. Suzanne writes, for example, "Il me semble, mon cher ami, que je ne t'ai jamais autant aimé que je le fais à présent. Le sentiment qui $\mathrm{m}^{\prime}$ attache à toi pénètre mon âme tout entière; je ne sens plus mon existence que par toi; je ne pense jamais à moi qu'en second, et c'est toujours par toi qu'il faut que je passe pour venir jusqu'à moi.." ${ }^{\prime \prime 1}$ She closes the letter in a similar vein writing: "Pour moi, je le sens, je n'ai qu'une âme, et c'est la tienne. Il faut $t^{\prime}$ aimer ou mourir." ${ }^{\prime 32}$ These would appear to be the words of a very good wife indeed and it is thus especially jarring to discover pointed negotiations buried in the middle of this same letter. Here, Suzanne Necker, obviously stung by Jacques Necker's criticism of her literary

27 Philippe Lejeune, On Autobiography. Ed Paul John Eakin. trans. Katherine Leary (Minneapolis: University of Minnesota Press, 1989), 167.

28 Ibid. 167.

29 Teresa McBride, "Public Authority and Private Lives: Divorce after the French Revolution" French Historical Studies 17, no. 3, 748.

30 Ibid. 748.

31 Haussonville, Salon, 2:9.

32 Ibid. 2:10 
ambitions, decides to make a deal with her husband, writing: "Ainsi, je viens faire mes conditions avec toi; dès l'instant que tu auras abandonné pour jamais la Compagnie des Indes, je te promets, si tu l'exiges, de renoncer à Fénelon et même à prendre la plume sur tout autre objet, et je souhaite de toute mon âme que le sacrifice que je te demande ne te coûte pas plus que celui que je te ferai." ${ }^{\prime 33}$ This passage was clearly jarring to Haussonville, who first published the letter and who is quick to assert that Suzanne Necker could not possibly have been aware of what she was asking of her husband. Not only does Haussonville suggest that Suzanne's request that Necker leave the Compagnie was ludicrous, but he also argues that only women could possibly be asked to "faire...le sacrifice des ambitions de leur vie" in the name of love. Finally, he suggests that Suzanne's request was actually due to jealousy of the Compagnie des Indes, which took her husband away from her: "cette jalousie plus noble qui voudrait posséder sans partage toutes les pensées et tous les instants de l'être aimé. ${ }^{\prime 35}$ In Haussonville's analysis, the Compagnie, and, indeed, all of the activities of Jacques Necker's public life from that point on, appear as menacing and threatening rivals for Jacques' affections. Suzanne Necker emerges from this reading as a naïve young woman who is wholly unaware of the demands and obligations of the public sphere and of the inherent gender hierarchies of the system. Because Suzanne was a good wife, however, she dutifully complied with her husband's wishes and stopped writing. This, at least, is what Haussonville suggests.

There is nothing necessarily wrong with this analysis, and perhaps Haussonville was right. After all, Jacques Necker was known to dislike the idea of femmes savantes, ${ }^{36}$ and while he may have suggested other-

33 The full quote reads: "Après cela, oses me reprocher que j'aime les lettres. Ce n'est plus, mon cher ami, qu'un reste d'habitude que je crois précieuse à conserver à cause de l'activité de mon âme et du vuide où ton absence me laisse. Mais ce reproche devient trop fréquent, et, quoique cette inquiétude te rende peut-être plus tendre, j'aime mieux être moins aimée, et que tu sois plus heureux. Ainsi, je viens faire mes conditions avec toi; dès l'instant que tu auras abandonné pour jamais la Compagnie des Indes, je te promets, si tu l'exiges, de renoncer à Fénelon et même à prendre la plume sur tout autre objet, et je souhaite de toute mon âme que le sacrifice que je te demande ne te coûte pas plus que celui que je te ferai" (Haussonville, Salon, 2:10).

34 Ibid. 2:11.

35 Ibid. 2:11.

36 See Danielle Johnson-Cousin,"Le théâtre de Necker. A propos d'inédits des Archives de Coppet," Revue de la société d'histoire du théâtre. 32, vol. 3 (1980): 220-31. 
wise in the flattering preface to his wife's Mélanges, Jacques Necker not only strongly discouraged Suzanne's writing, but also famously derided his daughter Germaine's childhood literary ambitions. ${ }^{37}$ In addition, Suzanne's overt affection for her husband, as witnessed by her salon guests, appeared to cement a flawless performance of the good wife, a role which, as Haussonville has argued, also involved the sacrificing of her own personal ambitions for the sake of those of her husband.

Critical to Haussonville's construction is a clearly gendered division between public and private, an analytical frame founded upon the idea of an inherently masculine public sphere and feminine private sphere. Within this conceptualization, women's writing is seen as an unruly or transgressive disruption which challenges the contours of social convention. For Haussonville, in other words, Suzanne Necker cannot be both writer and wife.

The implications of this are, of course, clear: within this formulation, Suzanne Necker, writer, cedes to Suzanne Necker, wife, and ultimately ceases to exist. Valérie Hannin and Dena Goodman are especially critical of this process. While Goodman, in a 1995 article, suggests that Jacques Necker's act of publishing Suzanne Necker as 'wife' has led to her complete and irrevocable erasure as writer, ${ }^{38}$ Valérie Hannin examines the problematic nature of Suzanne's legacy, arguing that the prevalence of posthumously published material makes it almost impossible to get close to Suzanne Necker on her own terms. ${ }^{39}$

But is the space between the public and the private unbridgeable? Are the acts of writing and 'wife-ing' inimical to one another? My reading suggests that while Suzanne's posthumous biographical construction - from Jacques Necker to Paul-Gabriel d'Haussonville - attempts

37 Germaine Necker, in her Journal de Jeunesse, observed that: "Mon père ne peut pas souffir une femme auteur...Il veut me mettre en garde contre cette faiblesse d'amour-propre. Maman avoit fort le gout de composer; elle le lui a sacrifié. 'Représente toi, me dit-il souvent, quelle étoit mon inquiétude, je n'osois entrer chez elle de peur de l'arracher à une occupation qui lui étoit plus agréable que ma présence. Je la voyois, dans mes bras, poursuivre une idée" in Andlau, Jeunesse, 109-110 (original spelling maintained).

38 Dena Goodman, "Suzanne Necker's Mélanges: Gender, Writing, and Publicity." In Going Public: Women and Publishing in Early Modern France, ed. Elizabeth C. Goldsmith and Dena Goodman (Ithaca: Cornell University Press, 1995), 211-23.

39 "Or, que sait on vraiment de Suzanne Necker? Il est frappant de constater que nous ne disposons, pour la connaître, que de souces indirectes, partiales ou tronquées" (Valérie Hannin, "Une ambition de femme au siècle des lumières: le cas de Madame Necker" Cahiers staëliens 36:5-29, p. 6). 
to separate the two, Suzanne's own writings and actions suggest that no such division existed in the woman herself.

Like Haussonville, I, too, begin with the letter. I turn in particular to that jarring moment of autobiographical rupture in which Suzanne Necker abruptly shifts from a tone of adoration and supplication to one of negotiation and then back again. What can we make of this statement, particularly in the light of the social and political situations which might have informed - either directly or indirectly - Haussonville's interpretation? And how might a rereading of that letter allow us to reposition - or at least to complicate - the biography of Suzanne Necker? In order to understand this moment of rupture, I turn to the theories of epistolarity espoused by Marie-Claire Grassi, and to the work of French feminist theorist Luce Irigaray.

Marie Claire Grassi argues that letter writing was an integral and essential element in elite sociability, an "acte de convivialité" implicated directly in the process of sociability. ${ }^{40}$ Within this matrix, Grassi identifies certain sylistic aspects as universal and others as gendered. Drawing directly on contemporaneous treatises on epistolarity, she argues that honnêteté, the underlying principle which governed eighteenthcentury behaviours, was specifically gendered in that women were required to employ a specific form of it. But she also suggests that women used the style recherché not in the service of coquetry, but rather as an indispensable strategy towards the authorization of the self within an otherwise masculine public sphere. ${ }^{41}$ Within this context, the letter functions as a form of seduction, in which the female writer's true intent is carefully veiled, masked under layers of carefully-staged propriety.

This idea relates directly to the theoretical frameworks put forward by French feminist theorist Luce Irigaray. Specifically, Irigaray argues that a woman's admission to the public sphere can only be successfully achieved through a process of mimesis. ${ }^{42}$ The lettre privée, then, read through the lens of seductive mimesis, becomes a space in which women might cloak themselves in propriety but speak differently. In other words, it becomes a subversive space through which a woman might undermine the very propriety that she appears to display, a process whereby the illusion of feminine propriety is deployed in the service of

40 Marie-Claire Grassi, “Épistolières au XVIIIe siècle," Lectrices d'Ancien Régime. Ed. Isabelle Brouard-Arends (Rennes: Presses universitaires de Rennes, 2003), 94.

41 Ibid. 101.

42 Luce Irigaray, This Sex Which Is Not One. trans. Catherine Porter (Ithaca: Cornell University Press, 1985), 76. 
the realization of the self. Such gendered and sexed letter writing can be said to exist in a specific domain.

The idea of epistolary specificity can deeply inform the ways in which we might choose to read Suzanne Necker's letter to her husband. As a seductive gesture, the letter cited by Haussonville, while couched within socially acceptable terms of submission and apology, becomes a subversive statement in which Suzanne publicly claims authority over her own voice and also, and perhaps more importantly, over her own autobiography. It is in this letter that Suzanne claims a 'room of her own' and sets out the limits to Jacques Necker's authority over her actions.

To avoid reading too much into Madame Necker's letter, however we need to accept that while she claims her space, she also, validates the qualities of what we - and Haussonville - might understand as integral to the 'good wife': she expresses neverending love for her husband to the extent of subsuming her own happiness entirely in his, and, more importantly, she appears to acquiesce to her husband's authority in matters of social propriety. What this apparent contradiction suggests is not that Suzanne repudiates the marriage contract, but rather that, even as Jacques Necker and Paul-Gabriel d'Haussonville suggest otherwise, she did not perceive the act of writing as inimical to that contract.

Suzanne Necker, even though Haussonville suggests otherwise, was not unaware of the difference between her position and that of her husband with regard to the activities of the public sphere. Not only do her own published and well-recognized political interventions demonstrate a clear interest in broader issues of public policy, but her personal writings as well allude to a keen awareness of the politics of governance. In an extended passage in the second volume of her Mélanges, for example, Suzanne directly links the governance of the domestic space of the salon with the very public governance of a state, for example. ${ }^{43}$ She also debunks the notion of the separation of the spheres by observing that the conversations of women could be as heated about politics as they were about sentiment. ${ }^{44}$ In claiming a space for her writing against her husband's wishes, she is well aware that she is transgressing gen-

43 "Le gouvernement d'une conversation ressemble beaucoup à celui d'un État" (Curchod Necker Mélanges, 2: 2).

44 "Le spectacle de Paris dans ce moment est impossible à décrire: l'opinoin parcourt tous les rangs; elle inspire, elle ralentit, elle attriste, elle désespère, elle prend toutes les formes et toutes les bouches....Les femmes parlent de la constitution avec la même chaleur qu'elles 
dered social norms, even as she simultaneously asserts the problematic nature of those norms.

I would suggest, therefore, that Haussonville was partially right: Suzanne Necker's request was ludicrous. But I believe that she was fully aware of the incongruity of her request. However, by choosing to juxtapose her work with his, Suzanne also pointed out the incongruity of his request. Suzanne Necker, by negotiating with her husband, not only asserted her obligation to be a good wife, as social custom decreed, but also, at the same time, her right to write.

All evidence suggests that fortunately Madame Necker did not stop writing, nor did she cease her public activities. Contemporaneous observers emphasize the powerful impact of Suzanne's public work, particularly that related to hospital reform. Not only does Jacques Necker, in his famous Compte Rendu of 1781, publicly acknowledge the charitable activities of his wife, ${ }^{45}$ a variety of other contemporaries, as well compliment Suzanne Necker directly on her work with the Hospice de Charite. ${ }^{46}$

At the same time, however, fortunately for Haussonville, all evidence suggests that Suzanne Necker was in fact a model wife. The reminiscences of salon guests suggest that Madame Necker was an uncommonly affectionate wife who clearly desired her husband's happiness. The Baroness d'Oberkirch writes that Suzanne and Jacques Necker "s'ennuyèrent point; mais ils ennuyèrent les autres et se mirent à s'adorer, à se complimenter, à s'encenser sans cesse, ils s'établirent en thuriféraires l'un de l'autre, surtout madame Necker devant son mari. ${ }^{\prime 47}$ Marmontel, too, one of the founders of the salon, comes to the uncomfortable conclusion that Suzanne's salon was created solely for

analysoient le sentiment à l'hôtel de Rambouillet" (Curchod Necker, Nouveaux Mélanges, 2:26).

45 "Sans doute il est précieux pour un Ministre des Finances d'avoir pu trouver dans la compagne de sa vie, un secours pour tant de détails de bienfaisance \& de charité qui échappent à son attention \& à ses forces; entraîné par le tourbillon immense des affaires générales, obligé souvent de sacrifier la sensibilité de l'homme privé, aux devoirs de l'homme public, il doit se trouver heureux que les plaintes particulières de la pauvreté \& de la misère, puissent aboutir près de lui à une personne éclairée qui partage le sentiment de ses devoirs" (Jacques Necker, Compte Rendu au Roi [Paris: Imprimerie Royale, 1781], 103).

46 Among them are Denis Diderot, Antoine-Léonard Thomas, and Georges-Louis Leclerc, Comte de Buffon.

47 Louise Henriette Waldner de Freunstein, Baronne d'Oberkirch. Mémoires de la Baronne d'Oberkirch ed. Suzanne Burkhard (Paris: Mercure de France, 1970), 190-191. 
her husband's pleasure and that the guests were essentially reduced to background scenery as a consequence. ${ }^{48}$

It is clear from the comments of contemporaries that Jacques and Suzanne Necker viewed themselves as an inseparable team. In this sense, the posthumously produced publications - not only the Réflexions, but also the Mélanges and Nouveaux Mélanges - can be seen to constitute a form of indissoluble marriage - a carefully nurtured republic of virtue in which each party to the negotiations played an integral role. Thus while I can divorce Suzanne from her biographical construction, I have a far harder time divorcing her from her husband. It is from this contradiction that a new biography can - and should - be written.

Ultimately, I believe that a new biographical approach can only be successful if scholars are willing to consider seriously the implications of writing the life of a woman who claimed authority over both a public, ambitious, autonomous, and individuated self, but who, at the same time, understood herself in the context of a profound relationship with another person; in other words, if we are willing to engage with a broader understanding of what constitutes a viable biographical subject. E. Lairtuillier, writing in 1840, offers a tantalizing possibility. By observing what appear to be analogous stylistic traits in the works of both Suzanne and Jacques Necker, Lairtullier argues that "nous n'hésitons pas à croire qu'elle y a fourni une grande part de travail." ${ }^{\prime 9}$ By suggesting that Suzanne Necker worked directly with her husband, Lairtullier hints at the possibility of an autobiographical pas-de-deux, in which Suzanne Necker, like Madame d'Épinay and Madame Roland, realized herself through a species of collaborative autobiography in which public and private selves do not resist one another, but rather are intrinsic to one another. Such a reading, which acknowledges Suzanne Curchod Necker as both wife and writer, might transform our understanding of her life. In the meantime, one thing is certain: Suzanne should not get divorced.

\section{SONJA BOON}

Simon Fraser University

48 Jean-François Marmontel, Mémoires de Marmontel (Paris: Librairie des bibliophiles, 1891).

49 Lairtullier, Femmes célèbres, 115. 